Осадча О. О., д.е.н., доцент (Національний університет водного господарства та природокористування, м. Рівне)

\title{
СИСТЕМА ВНТУРІШНЬОГО АУДИТУ СУБ'ЄКТА ГОСПОДАРЮВАННЯ В СУЧАСНИХ СОЦІАЛЬНО-ЕКОНОМІЧНИХ УМОВАХ
}

У статті досліджується сутність внутрішнього аудиту як важливої передумови ефективного функціонування суб'єкта господарської діяльності. Розглянуто особливості організації внутрішнього аудиту. Окреслено підходи до планування проведення внутрішнього аудиту. Вивчено напрями трансформації внутрішнього аудиту в сучасних соціально-економічних умовах.

Ключові слова: внутрішній аудит, якість внутрішнього аудиту, стандарти аудиту, ризики.

Існує пряма залежність між ефективним функціонуванням управлінської системи підприємства та його раціонально побудованою організаційною структурою, кваліфікованим і компетентним менеджментом, чітким розподілом функціональних обов'язків, повноважень та відповідальності персоналу, методами збирання і обробки інформації, системою його внутрішнього контролю.

Беззаперечним $є$ те, що в основі прийняття управлінських рішень лежить своєчасно отримана, повна та достовірна інформація щодо результатів господарської діяльності підприємства. Саме наявність такої якісної інформації забезпечує ефективність функціонування управлінських систем, знижує ймовірність помилок, дозволяє виключити чи мінімізувати значну частину ризиків.

Одним із основних джерел отримання такої інформації є матеріали аудиторських перевірок, які окрім фінансових даних, наводять аналіз результатів господарської діяльності, виявляють відхилення від вимог нормативно-правових актів, організаційно-розпорядчих документів, знаходять причини порушень, ймовірні фінансові, податкові та інші ризики.

У зв'язку з цим створення системи внутрішнього контролю, аудиту та управління ризиками є важливим інструментом управління суб'єктом господарської діяльності, необхідною умовою забезпечення ефективності його функціонування, фінансової стійкості, зростання інвестиційної привабливості та динамічного розвитку.

Зважаючи на те, що за останні роки посилення ролі внутрішнього аудиту стало чіткою тенденцією у всіх розвинених економіках, 
зросла кількість наукових досліджень та публікацій, присвячених аспектам його розвитку. Так, вагомий внесок у практичне становлення внутрішнього аудиту, створення високих стандартів професійної поведінки внесли праці американського науковця, колишнього президента Чиказького відділення Інституту внутрішніх аудиторів Роберта Р. Меллера «Brink's Modern Internal Auditing (Сучасний внутрішній аудит Брінка)», «IT Audit, Control, and Security (IT аудит, контроль і безпека)», «Sarbanes-Oxley and the New Internal Auditing Rules (Сарбейнс-Окслі і нові правила внутрішнього аудиту)», «Executive's Guide to COSO Internal Controls: Understanding and Implementing the New Framework (Керівництво щодо внутрішнього контролю COSO: розуміння і впровадження нової системи)». Проблемам забезпечення високої якості внутрішнього аудиту присвячена праця Саллі-Енн Піт «Internal Audit Quality: Developing a Quality Assurance and Improvement Program (Якість внутрішнього аудиту: розробка програми забезпечення і покращення якості)». Важливим джерелом актуальної науково-публіцистичної інформації щодо розвитку внутрішнього аудиту $€$ періодичне видання Інституту внутрішніх аудиторів «Internal Auditor Magazine (Внутрішній аудитор)».

Ряд вітчизняних науковців присвятили свої дослідження особливостям функціонування сучасного внутрішнього аудиту. Серед них слід відзначити роботи Редька О.Ю., Каменської Т.О., Петрик О.А., Білухи М.Т., Рудницького В.С., Семенець А.О.

Метою статті $є$ дослідження теоретичних та практичних аспектів формування сучасної системи внутрішнього аудиту підприємства, що передбачає виконання наступних завдань: за допомогою систематизації наукових підходів розкрити зміст поняття «внутрішній аудит», виокремити його особливості та завдання; запропонувати схему планування внутрішнього аудиту; вивчити вплив соціальноекономічного розвитку на функціонування внутрішнього аудиту.

Внутрішній аудит передбачає поточну діяльність внутрішньої аудиторської служби підприємства, яку, незалежно від назви, можна розглядати як окремий вид аудиторських послуг. Основні функції служби внутрішнього аудиту, як правило, складаються з процедур дослідження окремих операцій підприємства, оцінки цих операцій і контролю відповідності відображення їх в бухгалтерському обліку, а також контроль функцій внутрішньої системи контролю підприємства [1].

При створенні системи внутрішнього аудиту керівництву суб'єкта господарювання слід керуватися чинними нормативно-правовими актами, до яких належать: 
1. Кодекс етики працівників підрозділу внутрішнього аудиту (затверджений Наказом Міністерства фінансів України від 29.09.2011 № 1217, у редакції від 13.10.2017);

2. Стандарти внутрішнього аудиту (затверджені Наказом Міністерства фінансів України від 04.10.2011 № 1247, у редакції від 13.10.2017);

3. Code of Ethics (Кодекс професійної етики внутрішнього аудитора);

4. International Standards for the Professional Practice of Internal Auditing (Standards) (Міжнародні стандарти та практичні рекомендації внутрішнього аудитора, оновлена редакція дійсна 31 січня 2017 року).

Внутрішній аудит $є$ відносно новою системою контролю і має наступні особливості:

1) проводиться працівниками відділу внутрішнього аудиту (аудиторами) суб'єкта господарювання;

2) даний підрозділ вводиться за ініціативою керівництва підприємства;

3) інформація, отримана в результаті внутрішнього аудиту, призначена для потреб управлінського персоналу;

4) витрати, пов'язані з утриманням внутрішнього аудиту, є витратами суб'єкта господарювання.

В ході розвитку внутрішнього аудиту як органу внутрішнього контролю, в різні періоди часу перед ним ставилися різні завдання. На даний час можна виокремити такі основні завдання:

1) оцінка дотримання процедур;

2) оцінка складових внутрішнього контролю;

3) сприяння менеджменту в удосконаленні і реінжинірингу бізнес-процесів;

4) допомога в реалізації прийнятої стратегії бізнесу;

5) надання гарантій і консультацій замовникам (клієнтам) внутрішнього аудиту.

Проаналізувавши вищевикладене, можна зробити висновок, що внутрішній аудит $є$ сучасним органом контролю, який допомагає підприємству досягти поставлених цілей. Внутрішній аудит сприяє зростанню вартості суб'єкта господарювання, коли він орієнтований на попередження негативних подій, забезпечуючи при цьому об'єктивне підтвердження достовірності інформації і надаючи уявлення про результативність та ефективність процесів управління ризиками, внутрішнього контролю та корпоративного управління:

- підтвердження достовірності інформації - 3 питань корпоративного управління підприємством, управління ризиками і контролю, 
для допомоги підприємству у досягненні його стратегічних, операційних і фінансових цілей, а також завдань в контексті дотримання нормативно-регулятивних вимог;

- надання уявлення і розуміння - шляхом функціонування в якості каталізатора для підвищення ефективності та продуктивності підприємства через рекомендації, що засновані на об'єктивному аналізі, оцінці даних і бізнес-процесів.

Інститут внутрішніх аудиторів наполягає на тому, що аудиторський комітет підприємства повинен складатися не менше, ніж з трьох членів, більшість з яких повинна бути незалежними [2]. Зважаючи на об'єктивні умови функціонування вітчизняних підприємств досить часто відділ внутрішнього аудиту (внутрішня аудиторська служба) складається з однієї особи, що хоч і суперечить міжнародним нормативним документам, однак навіть у такому форматі існування посилює ефективність системи управління в цілому.

Головний виконавчий директор Інституту внутрішніх аудиторів Річард Чемберс виокремив 7 найважливіших характеристик, які повинні бути притаманні професійному внутрішньому аудитору [3].

1. Неупереджений і відкритий. Внутрішнім аудиторам платять за забезпечення роботи інших людей. Таким чином, особисті думки або упередження внутрішнього аудитора повинні контролюватися.

2. Доброзичливий i альтруїстичний. Хоча важливо, щоб звіти внутрішнього аудитора були неупередженими, це не означає, що він повинен бути неупередженим щодо цілей і забезпечення успішної діяльності підприємства. Коли працівники суб'єкта господарювання знають, що внутрішні аудитори дійсно працюють на благо підприємства, у них набагато більше шансів ефективно працювати разом.

3. Відкритий і прозорий. Для аудиторських клієнтів характерно бути більш відкритими і довіряти аудиторам, які відкриті і довіряють їм. Очевидно, що існують особливі ситуації, такі як перевірка на шахрайство, коли повна відкритість недоцільна. Але створення атмосфери відкритості найчастіше призводить до поліпшення результатів аудиту.

4. Чесний. Практично всі внутрішні аудитори визнають важливість чесності. 3 метою забезпечення довіри керівництва до рекомендацій внутрішніх аудиторів важливо, щоб їхні звіти відображали всі сторони проблеми.

5. Захоплений. Внутрішній аудитор повинен бути ентузіастом. Це особливо важливо зважаючи на те, що успіх внутрішнього аудиту залежить від переконання інших людей змінити поведінку. Це не тільки збільшує ймовірність позитивних змін, але і робить процес ау- 
диту цікавішим для всіх залучених сторін.

6. Надійний. На аудиторів потрібно розраховувати, а це означає, що вони повинні дотримуватися термінів і виконувати свої зобов'язання.

7. Постійний учень. Прихильність безперервної освіти $є$ чеснотою для всіх, але це особливо важливо для внутрішніх аудиторів. Міцна основа технічних навичок і галузевих знань має вирішальне значення, і оскільки робота внутрішнього аудитора охоплює весь спектр ризиків, з якими стикається сучасний бізнес, необхідно глибоке розуміння складнощів і нюансів бізнесу. Кращі внутрішні аудитори, як правило, щотижня залишають час в своїх розкладах для продовження освіти або інших заходів із самовдосконалення.

Важливим аспектом успішної діяльності служби внутрішнього аудиту $є$ глибоке і всебічно обгрунтоване планування, що враховує основні ризики суб'єкта господарської діяльності. Планування аудитів включає:

- довгостроковий план з урахуванням аналізу загальних ризиків;

- з'ясування необхідних кількісних і якісних ресурсів;

- формування річного плану та його затвердження;

- визначення об'єктів перевірок (філії, відділення, інші структурні і бізнес-одиниці, дочірні підприємства також входять в периметр аудиту в компаніях холдингового типу);

- оперативне планування.

При плануванні необхідно ставити в графік насамперед об'єкти з найгіршими оцінками за ризиками. При цьому треба прагнути до того, щоб контроль покривав усі аспекти діяльності суб'єкта господарювання (рисунок).

Якість внутрішнього аудиту суб'єкта господарювання безпосередньо залежить від розроблених стандартів, що визначають особливості його організації. Якщо ці стандарти не дотримуються або відсутні, проведення внутрішнього аудиту не буде ефективним.

Стандарти покликані забезпечити однозначне розуміння результатів перевірок як адміністрацією підприємства, так і керівниками об'єктів перевірки. Зазначені документи повинні регламентувати порядок проведення контрольних процедур і вимог до них, визначати основні принципи, вимоги, правила та етичні норми, яких слід дотримуватися при здійсненні внутрішнього аудиту та контролю.

Застосування стандартів дозволяє:

- зробити організацію проведення внутрішнього аудиту раціональнішою та ефективнішою, забезпечити додатковий контроль за роботою співробітників служби внутрішнього аудиту; 
- сприяти можливості використання в роботі наукових досягнень і нових технологій;

- посилити престиж внутрішнього аудиту;

- забезпечити високу якість внутрішнього аудиту, сприяти його вдосконаленню.

Розробка внутрішньофірмових стандартів повинна здійснюватися на основі міжнародних стандартів внутрішнього аудиту.

Система зазначених стандартів повинна містити настанови щодо принципів аудиту, управління програмами аудиту, оцінці системи внутрішнього контролю, створення механізму проведення оцінки систем внутрішнього контролю, проведення аудитів систем менеджменту, бізнес-процесів і інших питань функціонування суб'єкта господарської діяльності.

\section{Координація моделі ризиків і стратегії управління ризиками}

Етап 1. Окреслення цілей підприємства, розробка моделі ризиків:

- визначення стратегічних і оперативних цілей підприємства;

- розробка моделі ризиків (визначення меж категорій ризиків, визначення можливих розмірів збитків чи втрат і їх ймовірності).

\section{Аналіз виявлених ризиків}

Етап 2. Визначення сфер контролю, класифікація ризиків:

- виокремлення сфер контролю;

- визначення ризиків за сферами контролю;

- знаходження показників «розміри збитків чи втрат і ймовірності їх настання» за кожною сферою контролю в ризик-балах Risk-Score у формі картограми.

Розробка довгострокового плану внутрішнього аудиту

Етап 3. Складання плану контролю:

- розрахунок необхідних людино-днів для проведення внутрішнього аудиту за кожною сферою контролю на основі визначення складності контролю та оцінки ризиків RiskScore;

- опис методики внутрішнього аудиту за кожною сферою контролю;

- затвердження методики внутрішнього аудиту керівництвом суб'єкта господарювання.

Рисунок. Схема планування внутрішнього аудиту Складено автором за [4-5]

Загалом якість внутрішнього аудиту забезпечується:

- стандартами і регламентами;

- незалежністю, об'єктивністю і необмеженим доступом до ін- 
формації;

- професійною підготовкою і відповідністю персоналу;

- достатньою документацією для забезпечення перевірочних заходів;

- ефективним послідовним процесом внутрішнього аудиту;

- доступністю для перевірки всіх процесів і організаційних областей підприємства;

- системністю і комплексністю вирішення завдань внутрішнього контролю, аудиту та управління ризиками.

За останні роки вітчизняний внутрішній аудит в своєму розвитку просунувся значно вперед, однак внутрішнім аудиторам $€$ до чого прагнути. В епоху швидких змін і постійно мінливих ризиків бізнесу аудит, в тому числі і внутрішній, повинен трансформуватися. Зокрема, слід переглянути пріоритети щодо різних видів ризиків, виділяючи більше уваги можливостям інформаційних систем і технологій, кібербезпеці, а також стратегічним ризикам.

У відповідь на високий попит на сучасне мислення, яке відображає глобальні геополітичні та економічні впливи, Інститут внутрішніх аудиторів працює у напрямку «Глобальні перспективи та ідеї». Ця нова серія праць пропонує трактування ключових питань 3 перспективами, які резонують у глобальному масштабі.

Наприклад, у праці «Global Perspectives And Insights. 5G and the Fourth Industrial Revolution (Глобальні перспективи і точки зору. 5G і Четверта індустріальна революція)» [6] наголошується, що за очікуваннями експертів у 2021 році наступне покоління мобільного зв'язку стане реальністю, і це обіцяє стати квантовим стрибком у світі технологій. Великокаліберні аналітичні дані стануть більш цінними і необхідними для суб'єктів господарювання, які працюють з великими обсягами даних. Відповідно, буде зростати попит на тих фахівців, які володіють навичками аналізу даних, які можуть розкладати обсяги даних і переробляти їх на менші елементи, а також виокремлювати зміст та висновки для ділових операцій. При впровадженні 5G, вищому керівництву та внутрішньому аудиту слід розуміти, що суттєве збільшення кількості зібраних даних може призвести до додаткових фінансових та нефінансових ризиків, пов'язаних з даними.

Для внутрішнього аудиту буде надзвичайно важливим впровадження інтелектуальної автоматизації в епоху 5G, оскільки передбачається, що технологія дозволить відслідковувати та контролювати промислові процеси з рівнем точності, який ніколи раніше не спостерігався. Ця підвищена точність може не тільки допомогти виявити проблеми з якістю, але й підвищити безпеку на виробництві, заощадити кошти та потенційно поліпшити репутацію підприємства. 
Висновки. Якісна система внутрішнього аудиту відіграє важливу роль в удосконаленні процесів і процедур контролю, сприяє досягненню цілей суб'єкта господарювання у визначені строки. Довіра до функції внутрішнього аудиту та ії значимість зростає через залучення високопрофесійних кадрів із стратегічним мисленням, необхідними технічними та особистими навичками. У найближчі роки передбачаються значні трансформаційні зміні у роботі внутрішнього аудитора, спричинені Четвертою індустріальною революцією, що вимагатиме розуміння нових ризиків та пошуку нових інструментів та ресурсів.

1. Маліков В. В. Внутрішній аудит: аналіз проблематики та організація на підприємстві. Проблеми економіки, 2015. № 2. С. 147-152. 2. The Institute of Internal Auditors. Global Advocacy Platform, $2015 . \quad$ URL: http://www.iia.org.ua/wp-content/uploads/2015/04/Global-AdvocacyPlatform.pdf (дата звернення 18.08.2018). 3. Chambers R. 7 Characteristics of the Virtuous Internal Auditor. URL: https://iaonline.theiia.org/blogs/chambers/2019/Pages/7-Characteristics-of-theVirtuous-Internal-Auditor.aspx (дата звернення 18.08.2018). 4. Иванов О. Б. Организация внутреннего аудита в компаниях Германии. ЭТАП: экономическая теория, анализ, практика. 2013. Вып. 5. С. 129-142. 5. Толчинская М. Н. Риско-ориентированный подход в организации службы внутреннего аудита. Фундаментальные исследования, 2015. №10-3. С. 640-644. 6. The Institute of Internal Auditors. Global Perspectives And Insights. 5G and the Fourth Industrial Revolution. URL: https://global.theiia.org/knowledge/Pages/Global-Perspectives-andInsights.aspx (дата звернення 18.08.2018).

\section{REFERENCES:}

1. Malikov V. V. Vnutrishnii audyt: analiz problematyky ta orhanizatsiia na pidpryiemstvi. Problemy ekonomiky. 2015. № 2. S. 147-152. 2. The Institute of Internal Auditors. Global Advocacy Platform, 2015. URL: http://www.iia.org.ua/wp-content/uploads/2015/04/Global-AdvocacyPlatform.pdf (data zvernennia 18.08.2018). 3. Chambers R. 7 Characteristics of the Virtuous Internal Auditor. URL: https://iaonline.theiia.org/blogs/chambers/2019/Pages/7-Characteristics-ofthe-Virtuous-Internal-Auditor.aspx (data zvernennia 18.08.2018). 4. Ivanov 0. B. Orhanizatsiia vnutrenneho audita $\vee$ kompaniiakh Hermanii. $Э T A P$ : ekonomicheskaia teoriia, analiz, praktika. 2013. Vyp. 5. S. 129-142. 5. Tolchinskaia M. N. Risko-orientirovannyi podkhod $v$ orhanizatsii sluzhby vnutrenneho audita. Fundamentalnye issledovaniia, 2015. № 10-3. S. 640-644. 6. The Institute of Internal Auditors. Global Perspectives And Insights. 5G and the Fourth Industrial Revolution. URL: https://global.theiia.org/knowledge/Pages/GlobalPerspectives-and-Insights.aspx (data zvernennia 18.08.2018).

Рецензент: д.е.н., проф. Левицька С. О. (НУВГП) 
Osadcha 0. 0., Doctor of Economics, Assosiate Professor

(National University of Water and Environmental Engineering, Rivne)

\section{INTERNAL AUDIT ENTITY IN MODERN SOCIO-ECONOMIC CONDITIONS}

The article examines the essence of internal audit as an important prerequisite for effective functioning of a business entity. It is determined that internal audit implies ongoing activities of the internal audit service of the enterprise, which can be considered as a separate type of audit services. It is substantiated that internal audit contributes to the value increase of an entity when it is focused on the prevention of adverse events, while providing objective confirmation of the reliability of information and providing insight into the effectiveness and efficiency of risk management, internal control and corporate governance processes. Approaches to planning of internal audit are outlined; its planning scheme is formed. It is determined that the quality of the internal audit of an entity directly depends on the developed standards that determine the features of its organization. The directions of transformation of internal audit in modern socio-economic conditions, namely with the introduction of $5 \mathbf{G}$, are studied.

Keywords: internal audit, quality of internal audit, audit standards, risks.

Осадчая О. А., д.э.н., доцент (Национальный университет водного хозяйства и природопользования, г. Ровно)

СИСТЕМА ВНУТРЕННЕГО АУДИТА СУБЪЕКТА ХОЗЯЙСТВОВАНИЯ В СОВРЕМЕННЫХ СОЦИАЛЬНО-ЭКОНОМИЧЕСКИХ УСЛОВИЯХ

В статье исследуется сущность внутреннего аудита как важной предпосылки эффективного функционирования субъекта хозяйственной деятельности. Рассмотрены особенности организации внутреннего аудита. Определены подходы к планированию проведения внутреннего аудита. Изучены направления трансформации внутреннего аудита в современных социально-экономических условиях.

Ключевые слова: внутренний аудит, качество внутреннего аудита, стандарты аудита, риски. 